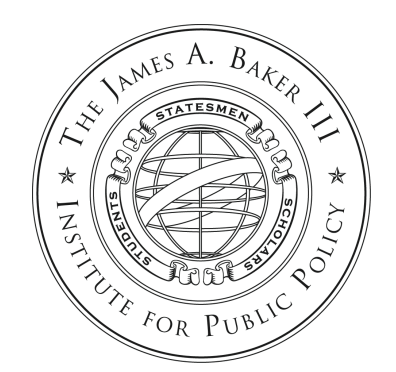

James A. BAker III Institute for Public Policy

RICE UNIVERSITY

\title{
NeW Alignments? \\ The Geopolitics of Gas and OIL Cartels AND THE CHANGING MIDDLE EAST
}

\author{
BY \\ Songying Fang, Ph.D. \\ Assistant Professor of Political Science \\ RICE UNIVERSITY \\ AMy MyERS JAFFE \\ Wallace S. Wilson Fellow in Energy Studies \\ JAMES A. BAKER III INSTITUTE FOR P UBLIC POLICY \\ RICE UNIVERSITY \\ Ted Temzelides, Ph.D. \\ Rice Scholar, James A. Baker III Institute for Public Policy \\ Professor of ECONOMICS, Rice UnIVERSITY
}

JANUARY 2012 
THESE PAPERS WERE WRITTEN BY A RESEARCHER (OR RESEARCHERS) WHO PARTICIPATED IN A BAKER INSTITUTE RESEARCH PROJECT. WhEREVER FEASIBLE, THESE PAPERS ARE REVIEWED by OUtSIDE EXPERTS before they ARE RELEASED. HOWEVER, THE RESEARCH AND VIEWS EXPRESSED IN THESE PAPERS ARE THOSE OF THE INDIVIDUAL RESEARCHER(S), AND DO NOT NECESSARILY REPRESENT THE VIEWS OF THE JAMES A. BAKER III INSTITUTE FOR PUBLIC POLICY.

(C) 2012 By the james A. BAker III Institute for Public Policy of Rice University

THIS MATERIAL MAY BE QUOTED OR REPRODUCED WITHOUT PRIOR PERMISSION, PROVIDED APPROPRIATE CREDIT IS GIVEN TO THE AUTHOR AND THE JAMES A. BAKER III INSTITUTE FOR PUBLIC POLICY. 
The Geopolitics of Gas and Oil Cartels and the Changing Middle East

\section{ACKNOWLEDGMENTS}

We wish to thank David Mares, Edward Morse, and Kristopher W. Ramsay for their valuable comments and suggestions. We also thank Keily Miller and James Coan for their excellent research assistance. All errors are the sole responsibility of the authors. 


\title{
The Geopolitics of Gas and Oil Cartels and the Changing Middle East
}

\begin{abstract}
We analyze the likelihood of different coalitions emerging in energy markets in light of two new transformational events: the Arab Awakening and the rise of shale gas in the United States. Our analysis considers both economic and political payouts resulting from alternative energy policies of three major petro-powers: Saudi Arabia, Russia, and Qatar. We discuss the likelihood of price wars in energy markets and identify two conditions under which price wars can occur. There can be a price war in the gas market if Russia is determined to protect its market share in Europe by knocking out other higher cost producers. We find that competitive pressures created by shale gas could make this option more appealing to Russia. Second, Saudi Arabia can generate an oil price war as a foreign policy tool in order to weaken Iran's position as a rival to the Kingdom. Finally, we consider the recent democratization movement in the Middle East. Significant changes in geopolitical payouts may bring about new coalitions involving Russia. Nevertheless, we find that a gas cartel is unlikely to form in the perceivable future.
\end{abstract}

\section{Introduction}

Throughout the modern period, resource producers have sought to form coalitions in order to enhance their economic power. One of the most successful coalitions is the Organization of Petroleum Exporting Countries (OPEC), which rose to global influence in the 1970s amid international shortages of oil. In the last five years, one of the most striking developments in the global energy landscape has been the dramatic rise in the prospects for natural gas as a global fuel. Enthusiasm for this fuel source is gaining momentum, and the likelihood that natural gas will play a major strategic role in the world economy is growing. The new gusto for natural gas is partly a product of its many attractive attributes (particularly its relatively low-carbon emissions when compared with other fossil fuels), and partly a result of its growing availability, as rising supplies from shale become available in North America. Russia, one of the world's largest natural gas reserve holders, was quick to respond to this growth in global natural gas demand by building new pipelines, as well as lobbying for a gas cartel to counterbalance the competitive market influence resulting from rising shale gas supplies. Simultaneously, as it focused on the geopolitical leverage it could achieve as a petro-exporter, Russia expressed 


\section{The Geopolitics of Gas and Oil Cartels and the Changing Middle East}

interest in joining OPEC formally. ${ }^{1}$ If Russia were able to form either a gas or oil coalition with other important exporters from the Middle East, it would significantly change the way that the energy markets operate and, consequently, influence the geopolitics of energy and international relations more generally.

In this study, we investigate three related questions raised by the above observations. First, what is the likelihood that Russia will be successful in creating new coalitions in energy markets in the near future? Russia's aggressive use of its own energy exports as a tool of statecraft and diplomatic leverage in recent years has reintroduced fears of an "energy weapon" that could be wielded in international discourse. It has been argued that tightening energy markets could raise the benefits and possible chances of success for an energy exporting country that, alone or in combination with others, is trying to wrest political concessions by threatening to cut off energy supplies. Such an event would present a challenge for the international economy, and it could even lead to military conflict. ${ }^{2}$ Second, even if new coalitions involving Russia are not imminent, in light of the recent political developments in the Middle East, how would the likelihood of the coalitions change as a result of the evolving relationship between the United States and the major resource producers in the region? Finally, in the event that prolific shale gas resources prevent energy markets from tightening further and indeed reverse the trend, will low-cost major oil and gas exporters such as Russia, Qatar, or Saudi Arabia engage in price war tactics? Oil and gas production from shale is vulnerable to competitive pressures due to its high costs of recovery technique.

Historically, the United States' close security relations with two major energy suppliers in the Mideast—Saudi Arabia (the world's largest oil exporter) and Qatar (the world's largest liquefied natural gas exporter) - have limited Russia's ability to achieve resource rent-seeking alliances in the Middle East. In recent years, however, Russia has tried to tap its large energy resource endowments to reassert its place as a global superpower. ${ }^{3}$ However, such exports have not been well received by important members of OPEC, and the public discussion of Russia joining OPEC has made little progress. ${ }^{4}$ Similarly, Russia's initial efforts to create a gas cartel have been unsuccessful. In 2009, Russian gas industry leader Alexander Medvedev suggested that a gas troika of Iran, Qatar, and Russia consider joint "projects that could be implemented by the three 


\section{The Geopolitics of Gas and Oil Cartels and the Changing Middle East}

countries in gas production and transportation." Addressing a December 23, 2008, gathering of the Gas Exporting Countries Forum (GECF), a loose grouping of natural gas producers, Prime Minister Vladimir Putin hinted that a gas producer group might be rent-seeking. Because the cost of extracting gas was rising sharply, Putin contended that "the era of cheap energy resources, of cheap gas, is of course coming to an end." "Still, while Russia has, at the highest levels, approached the leadership of its biggest liquefied natural gas (LNG) or pipeline gas competitors in Iran, Libya, Algeria, and Qatar, so far it has failed to create convincing partnerships that could serve as the basis for cartelization.

Despite the apparent failure of new coalitions to emerge in the energy market, there has been continuing speculation about the prospect of a gas cartel in the imminent future. Some analysts have weighed in on the question, and their answers tend to be negative. The reasons proposed range from a collective action problem that prevents members of the GECF to reach an agreement $^{7}$ a fragmented gas market structure, ${ }^{8}$ and an imbalance of surplus supply potential versus demand that is likely to prevent a cartel of producers from gaining sufficient monopoly power in the market. ${ }^{9}$ What is noticeably missing in the existing literature is an analysis of whether the geopolitical interests of key players are lined up in such a way that makes new coalitions desirable. In other words, the existing studies have not taken into account how the foreign policy interests of the major gas and oil producers interact with their economic interests in making higher profits. In addition, the possibility of a new gas cartel has been discussed solely from the perspective of the gas market. However, oil and natural gas serve as substitutes in many economic sectors and, moreover, Russia is a major producer in both markets. Thus, its strategies on oil and gas are likely to be interconnected. Falling natural gas prices relative to oil make interconnectedness a more compelling consideration by major producers. We address these issues in this study.

Using a game-theoretic approach, we focus on the choices faced by three major resource producers in the world: Russia, Saudi Arabia, and Qatar. The activities of these producers generate much of the dynamics in energy markets. ${ }^{10}$ Russia is a key player in both oil and gas markets, while Saudi Arabia is primarily an oil producer and the price-setter for international oil prices. Qatar, primarily a gas producer, is the largest supplier of globally traded LNG and has 


\section{The Geopolitics of Gas and Oil Cartels and the Changing Middle East}

recently gained a price-setting role in natural gas markets as LNG trade has rapidly expanded. While Russia is currently free-riding on high oil prices set by OPEC, Russia was also clearly hurt by oil price wars waged by Saudi Arabia in the mid-1980s. Additionally, competition from Qatar in the gas market has significantly cut into Russia's economic interests in the past two years and is actively lessening Moscow's geopolitical influence. Consequently, there has been speculation about how Russia might respond to the threat that both Saudi Arabia and Qatar could further weaken its global position through future oil and gas price wars. Will Russia be able to form coalitions with these two key players in order to avoid price wars? Alternatively, will its stronger, semi-privatized oil industry of today better position Russia to withstand and even win a potential price war? We touch on these issues as we address broader questions of the interplay between the two markets and their likely long-term developments in response to changing regional and global political environments.

The strategic nature of the relationships makes game theory an appropriate analytic tool for our study. In addition to economic returns, the payoffs to the corresponding countries involve significant geopolitical components, which are inherently interdependent. Therefore, identifying the geopolitical interests of the respective countries and analyzing their importance relative to their economic interests are central to our analysis. ${ }^{11}$ Moreover, as the markets for oil and natural gas are interconnected, we adopt a cooperative game-theoretic framework in order to analyze potential coalition formations in the two markets simultaneously. As we mentioned earlier, oil and natural gas can serve as substitutes in some cases, most directly through the use of fuelswitching equipment or, in other cases, through the investment of technologies to permanently change equipment to burn one fuel versus the other. Over the past two decades, natural gas has made strong gains as a substitute for oil as a fuel for electricity generation and industrial activity, as a feedstock for the manufacturing of petrochemicals, and in residential heating. This substitutability of natural gas for oil is expected to grow in the coming years, as new conversion technologies allow natural gas to enter the transportation sector more easily through an increase in the number of gas-to-liquids processing plants, compressed natural gas car engines, and indirectly through electric cars. 


\section{The Geopolitics of Gas and Oil Cartels and the Changing Middle East}

One of the central findings of our analysis is that geopolitical considerations can be dominant and may determine a very different outcome from that prescribed solely by economic considerations. Specifically, our analysis shows that one explanation for Russia's failure to strike new energy coalitions is the ongoing oil-for-security relationship that Saudi Arabia and Qatar have maintained with the United States. Importantly, our analysis also sheds light on how the status quo may change in response to new political developments in the Middle East. We argue that the uprisings and democratization movements in the Middle East may compel Saudi Arabia to pay more attention to its domestic needs and, thus, elevate the importance of economic payoffs from its oil resources above geopolitical payoffs from a special Saudi-U.S. relationship. The consequence could be a Saudi-Russia coalition in the oil market. Saudi Arabia's incentive to form such a coalition will become stronger if Russia can also help contain Iranian nuclear ambitions. On the other hand, our analysis suggests that the possibility of a gas cartel between Russia and Qatar is less likely.

The rest of the paper proceeds as follows: In the next section we present our assumptions about the key players' preferences regarding their foreign policy goals. We then combine the assumptions with a simple cooperative game-theoretic model to identify the most plausible coalitions. In the section following the modeling exercise, we discuss in detail whether these coalitions are likely to materialize under the current environment. Our analysis suggests that the answer to this question is negative. We then address a natural question that arises from the finding that the status quo is stable: the likelihood of price wars. Finally, we investigate whether new coalitions are more likely to emerge due to the uprisings and democratization movements in the Middle East and the potential decline of U.S. influence in the region. We conclude with a summary of our findings.

\section{Assumptions}

In this section we discuss the preferences of the key participants regarding the potential outcomes of their foreign policies. For the purposes of our modeling, we assign Saudi Arabia three main foreign policy objectives: maintaining a strategic partnership with the United States, which is fundamental to its security; maximizing the economic and geopolitical benefits from 


\section{The Geopolitics of Gas and Oil Cartels and the Changing Middle East}

being the most important oil producer in the world; and maximizing its global and regional political influence. These three dimensions are certainly not independent of each other; in particular, Saudi Arabia's global and regional influence is partly due to its special relationship with the United States and its status as the most influential player in the oil market. Saudi Arabia is the only nation that currently has the power to raise or lower the price of oil single-handedly. However, Saudi Arabia also derives its influence in international and regional affairs from its position as the spiritual leader of the Arab world due to its important role as the guardian of Islam's holiest religious sites and from its wealth, which is used to support its branch of Islamic teaching and practice in other countries. Despite the interdependence of the three main foreign policy objectives, for conceptual clarity, we find it useful to treat them as distinct.

Moreover, we will postulate that when these three objectives cannot be accommodated simultaneously, particularly when the first two objectives clash, national security takes precedence. In other words, Saudi Arabia prefers an outcome that protects its special relationship with the United States over alternative outcomes that would imply higher economic benefits or global and regional influence. We believe that this is a reasonable premise. Saudi Arabia's policies in response to Iraq's 1990 invasion of Kuwait are a prime example of this preference.

Second, we postulate that Qatar has three foreign policy objectives: maintaining a strategic partnership with the United States, maximizing the economic benefits from being the major gas producer, and promoting its global and regional influence (in particular, in a manner that is independent of the regional power of Saudi Arabia). Like Saudi Arabia, Qatar's regional influence is mainly a function of its special relationship with the United States and its role as the world's leading producer of LNG. Qatar enjoys additional influence through a multi-directional foreign policy, for example, through the soft power of its government-supported and controlled satellite television network, Al Jazeera, and through actively engaging in regional diplomacy. As in the case of Saudi Arabia, we postulate that the geopolitical payoffs for Qatar from its relationship with the United States eclipse its economic payoffs as well as its payoffs from having other tangible influence in global and regional affairs. ${ }^{12}$ 


\section{The Geopolitics of Gas and Oil Cartels and the Changing Middle East}

For the purposes of this exercise, we concentrate on two main foreign policy objectives for Russia: reasserting its status as a major power in international politics, and deriving maximal economic benefits from being a major oil and gas producer. ${ }^{13}$ Moreover, we postulate that Russia values its major power status more than the economic benefits from the oil and gas markets when the two goals are at odds with each other. This postulate has been demonstrated in numerous ways, including by Russia's willingness to sell oil or gas at discounted prices to allied neighboring countries, as well as by its wariness to increase export revenues by allowing stranded oil and gas in the Russian Far East to be developed for export via pipeline to China due to territorial, border related suspicions of Chinese intentions. ${ }^{14}$

\section{Model}

Here we develop a cooperative game-theoretic model to analyze the questions raised in the previous section. This approach allows us to identify outcomes that are stable (or in the core, i.e. the set of all feasible outcomes that cannot be improved upon by any coalition) versus those that are not. Unstable outcomes can be improved upon by a coalition of participants; as we assume that all participants are rational, we will conclude that such outcomes are unlikely to emerge. ${ }^{15}$ We will concentrate on outcomes that are immune to potential improvements by different coalitions of producers. We will say that a coalition "C" blocks or improves upon an outcome if there is another feasible outcome that makes all members of the coalition strictly better off. ${ }^{16}$

We model the interaction between three players: Russia (R), Qatar (Q), and Saudi Arabia (S). Consistent with our earlier discussion, we will assume that Russia is a producer in both energy markets, while Saudi Arabia is only an oil producer and Qatar only a gas producer. We note that this approach is an instructive proxy for conditions in the world energy market where some big players are mostly gas exporters, others only oil exporters, and still others export both oil and gas. Given the respective roles of Russia, Qatar, and Saudi Arabia in the two markets, there are six plausible outcomes with respect to the relationships between the three countries in the two markets. We enumerate these outcomes below. Note that we use RO and RG to refer to Russia's roles as an oil producer and a gas producer, respectively. 


\section{The Geopolitics of Gas and Oil Cartels and the Changing Middle East}

1. $\left\{\mathrm{R}_{\mathrm{O}}, \mathrm{S}\right\},\left\{\mathrm{R}_{\mathrm{G}}, \mathrm{Q}\right\}$ : Russia forms a cartel with Saudi Arabia in the oil market and forms a cartel with Qatar in the gas market.

2. $\left\{\mathrm{R}_{\mathrm{O}}, \mathrm{S}\right\},\left\{\mathrm{R}_{\mathrm{G}}\right\},\{\mathrm{Q}\}$ : Russia forms a coalition with Saudi Arabia in the oil market while Russia and Qatar operate independently in the gas market.

3. $\left\{\mathrm{R}_{\mathrm{O}}\right\},\{\mathrm{S}\},\left\{\mathrm{R}_{\mathrm{G}}, \mathrm{Q}\right\}$ : Russia and Saudi Arabia operate independently in the oil market while Russia forms a cartel with Qatar in the gas market.

4. $\left\{\mathrm{R}_{\mathrm{O}}, \mathrm{R}_{\mathrm{G}}\right\},\{\mathrm{S}\},\{\mathrm{Q}\}$ : Russia, Saudi Arabia, and Qatar all operate independently in both markets.

5. $\left\{\mathrm{R}_{\mathrm{O}}, \mathrm{R}_{\mathrm{G}}\right\},\{\mathrm{S}, \mathrm{Q}\}$ : Russia operates independently in both markets while Saudi Arabia and Qatar form a cartel over both oil and gas markets.

6. $\left\{\mathrm{R}_{\mathrm{O}}, \mathrm{R}_{\mathrm{G}}, \mathrm{S}, \mathrm{Q}\right\}$ : Russia, Saudi Arabia, and Qatar form a coalition in both oil and gas markets.

Imbedding in the model our assumptions about the countries' preferences over foreign policy outcomes, we argue that some of the above outcomes are not plausible. In other words, certain coalitions are not in the core, as they can be improved upon by some other coalitions.

First, we argue that outcomes 1 and 2 cannot be in the core because Saudi Arabia will be significantly better off both geopolitically and economically by leaving the coalition and acting unilaterally. Geopolitically, an alliance with Russia would presumably dilute Saudi Arabia's special relationship with the United States and reduce its access to U.S. protection and military assistance, which will negatively affect its security vis-à-vis its regional rival, Iran. Damage to the U.S.-Saudi relationship might also weaken Riyadh's international and regional influence. ${ }^{17}$ From an economic point of view, instead of single-handedly influencing oil prices, Saudi Arabia would have to share that power once it forms a coalition with Russia. Moreover, by having an oil cartel between Saudi Arabia and Russia, oil consuming countries would be even more motivated 


\section{The Geopolitics of Gas and Oil Cartels and the Changing Middle East}

to diversify their energy usage away from oil and would likely seek out Qatar and other natural gas producers as a means of diversification. Taking both economic and geopolitical factors into consideration, it appears more plausible that Saudi Arabia would rather go it alone, regardless of whether Russia forms a cartel with Qatar in gas production or not. We conclude that Saudi Arabia can unilaterally improve upon outcomes 1 and 2.

Second, we argue that outcome 5 cannot be stable. Constrained by Saudi Arabia in such a coalition, Qatar will be worse off in terms of deriving economic benefits and exercising international and regional influence. Economically, by emphasizing LNG exports, it has made its income stream largely separate and independent from Saudi Arabia. The shift in Qatar's energy portfolio toward natural gas has allowed the tiny country to move to a commodity on which Saudi Arabia has a less dominating influence and that fits with Qatar's desire to obtain greater independence from Saudi Arabia ${ }^{18}$ and "attain economic and security relationships that were outside direct Saudi control."19 Qatar has also brought in American firms to develop its natural gas, hoping to strengthen its security relationship with the United States. ${ }^{20}$ The move to natural gas has paid off handsomely, as Qatar is now the largest exporter of LNG in the world and boasts the highest per capita gross domestic product in the world.

Qatar's dominant role in the global LNG market gives it additional international stature. It would not want Saudi Arabia to be able to dictate its gas policies and thereby dilute the power and influence it gets from being the major supply alternative to Russia and serving as a major natural gas supplier to China, Japan, and South Korea. Additionally, because natural gas is a substitute for oil, Saudi Arabia would prefer to have less competition from natural gas. Thus, in an alliance with Qatar, Saudi Arabia would likely try to restrain Qatar's ability to provide a competing fuel.

Finally, by being an independent gas supplier, Qatar becomes more important geopolitically and is able to strengthen its independent security relationship with the United States. Recognizing the importance of Qatar's natural gas, the U.S. government since 1996 has provided more than \$2 billion in loan guarantees via the Export-Import Bank to support various natural gas development

projects in Qatar. ${ }^{21}$ In 2003, the U.S. Combat Air Operations Center for the Middle East moved from Saudi Arabia to Qatar's Al-Udeid air base. The Qatari base and other facilities now "serve 


\section{The Geopolitics of Gas and Oil Cartels and the Changing Middle East}

as logistics, command and basing hubs for the U.S. Central Command (CENTCOM) area of operations, including Iraq and Afghanistan.",22

Qatar maintains close strategic relations with the United States "as a balance to the influence of powerful neighbors in Saudi Arabia and Iran." 23 An alliance with Saudi Arabia would give the Saudis more sway in trying to limit Qatar's independent foreign policy. Thus, we argue that the coalition $\{Q\}$ improves upon outcome 5 regardless of what the other countries do. This leaves us with 3, 4, and 6 as viable candidates for stable outcomes. Outcome 4, where the three countries are operating independently, is in fact the status quo. Thus, our analysis provides an explanation for the emergence and maintenance of the current status quo. Other plausible alternatives are a gas cartel between Russia and Qatar (outcome 3), and a grand coalition of all three countries (outcome 6). In the remainder of the paper, we analyze under what conditions changes in geopolitical and economic conditions might give rise to a change in the status quo.

\section{Gas Cartel: An Unlikely Coalition}

Given our analysis so far, there are only two scenarios in which a gas cartel can potentially emerge. The first is if all three countries come together and form a grand coalition of gas and oil (outcome 6). Indeed, it can be plausibly argued that, purely in terms of economic payoffs, the three countries involved would experience the greatest payoffs when they form a grand coalition. However, we will argue that this scenario is highly unlikely. This is a central finding of our analysis - namely, when geopolitical considerations are taken into consideration, they may determine a very different outcome from that prescribed solely by economic considerations. More precisely, while it is true that — having both oil and gas reserves-Russia is better off in the cartel scenario both economically and geopolitically, the same cannot be said for Qatar and Saudi Arabia.

For Qatar, a grand coalition can eliminate the possibility of a price war with either Russia or Saudi Arabia. This would increase Qatar's revenue, but the increase would not be substantial. This is because there is an oversupply of gas in the world due to fringe supplies from the United

States, Canada, Australia, etc. As a result, it is difficult to raise the gas price significantly. ${ }^{24}$ On 


\section{The Geopolitics of Gas and Oil Cartels and the Changing Middle East}

the other hand, being in the grand coalition would weaken Qatar's relationship with both the United States and the EU, while it would increase the political influence of Saudi Arabia in international affairs, thus, negatively affecting Qatar's geopolitical interests. In the end, we believe a strong case can be made that the increase in economic benefit from joining the grand coalition will not be enough to offset Qatar's loss in the geopolitical arena.

Perhaps more importantly, Saudi Arabia does not have an incentive to form such a coalition. Currently, Saudi Arabia already enjoys enormous economic gains from relatively high oil prices, and the Kingdom's limited economy has difficulties absorbing a sudden influx of petrodollars that arise from oil prices that are unsustainably high. Experience shows that temporary profits from unusually high oil prices are often lost because they must be immediately reinvested in global financial markets that are prone to overheat. ${ }^{25}$ In addition, high oil prices can result in a global recession, which would quickly curtail long-term demand for Saudi oil. This suggests that the additional economic gains from the grand coalition may not be all that enticing for Saudi Arabia, as they would likely come at the cost of losing some of the geopolitical leverage that the country currently enjoys. Saudi Arabia derives much of its power from its important role as the "central bank" of international oil. Since the 1970s, Saudi Arabia has served as the global swing producer, adding oil to markets when prices rise too high and threaten the global economy, and cutting its production when low prices prove destabilizing to important oil producing regions. Saudi Arabia's ability to single-handedly alter the price of oil gives the Kingdom significant geopolitical power. Saudi Arabia has used its ability to lower the price of oil to its geopolitical advantage on many occasions over the decades. With this oil superpower stature comes the bargaining power that Saudi Arabia enjoys on the international stage, including its new and prized position in the G-20.

This leaves us with the only other alternative to the status quo, outcome 3 . This is often touted as the most plausible scenario, given that Russia is eager to solve the problem of a potential "twofront economic war" with both Qatar and Saudi Arabia. In this scenario, Russia forms a gas coalition with Qatar, while it remains in a competitive relationship with Saudi Arabia in the oil market. One aspect of this scenario is that, having both resources, Russia will have an incentive to use the cartel to advance its overall interest, while Qatar will be constrained on the gas market 


\section{The Geopolitics of Gas and Oil Cartels and the Changing Middle East}

and weakened geopolitically by losing its special relationship with the United States and Europe. As we mentioned, this relationship derives, in part, from its important role as an alternative supplier of natural gas in competition with Russia. Indeed, Russia's past behavior toward its smaller neighbors and trading partners demonstrates little reluctance to use bullying tactics to gain uneven economic advantages. Since the 1990s breakup of the former Soviet Union, Russia has used its control of regional pipelines to trap Caspian natural gas supplies and to capture the rents from these resources for its own benefit. For example, until Turkmenistan recently forged new pipeline connections to China, Moscow's pipeline trading monopoly from the region effectively locked in cheap Turkmen gas imports for its own economy at depressed prices of $\$ 150$ per thousand cubic meters. At the same time, Russia exported its own gas at twice the profit to high-paying Western European customers. We conclude that Qatar would be reluctant to form a coalition with Russia, as history suggests that Russia would use such an alliance to advance its own economic interests at Qatar's expense.

\section{Will the Status Quo Lead to Price Wars?}

Our analysis so far suggests that the status quo relationship between the world's largest suppliers of oil and natural gas is stable. However, stability in the status quo configuration of geopolitical interests does not rule out the possibility of price wars between the players. We refer to a price war as a situation where the oil/gas producing countries competitively reduce prices in order to make zero sum gains in market share at each other's expense. Moreover, as was the case for Saudi Arabia in the 1980s, a price war can be launched to achieve geopolitical ends. In this section we examine both economic and political considerations that may lead any of the three countries to wage a price war. We will argue that price wars are unlikely in the current geopolitical environment. However, we also point out that they may occur if domestic and international economic and political conditions change.

In principle, each of the three countries can wage a price war, so we consider all possibilities in turn. We first discuss the possibility of a price war in the gas market between Qatar and Russia, and then discuss the possibility of a price war in the oil market between Saudi Arabia and Russia. 


\section{The Geopolitics of Gas and Oil Cartels and the Changing Middle East}

We consider a price war in natural gas first, since major exporters are already under competitive market pressures from the prospect of rising shale supply. As it can produce gas at very low cost, Qatar is capable of waging a price war in the gas market. The purpose of such a move could be to crowd out Russia or other competitors. In a sense, this is the status quo, as Russia saw a 10 percent drop in exports to Europe in 2010, even after dropping its own prices considerably. Clearly, Russia has an incentive to change the situation despite not being able to form a gas cartel with Qatar. Indeed, Russia could respond by slashing its own prices further, thus protecting and even expanding its market share and potentially enhancing its geopolitical ties with new customers. Some of the revenue lost by lower prices could be made up with higher volumes of sales. Russia might have trouble competing with Qatar in certain markets, like Asia, given Qatar's extremely low cost of production, but it could knock out other higher cost producers selling to Europe. Russia could also benefit geopolitically from this strategy, as the Caspian states, which Russia would like to keep in its sphere of influence, are among the highest cost gas producers. By ending the possibility of Caspian gas exports to Europe, Russia could weaken ties between the Caspian states and Europe, leaving the Caspian states more dependent on non-energy trade with Moscow and thereby giving Moscow greater influence in that region. Another geopolitical benefit to Russia could result if European buyers are eventually attracted to very cheap Russian energy supply, improving Russia's ability to woo Europe away from the U.S. alliance. Over time, as high-cost production (including shale gas) is replaced by supplies from Russia and Qatar, Russia would again have higher market share and thereby regain more leverage over a larger number of buyers, possibly winding up better off in the long term despite the short-run loss in revenue.

However, there is one caveat: Increasing production of natural gas will require Russia to reform its domestic gas policies. This is not a trivial task given the government's concern for domestic political stability. Gazprom, Russia's state natural gas monopoly, has been lobbying to offset financial losses from lower prices and exports to Europe by increasing prices inside Russia, where it makes the bulk of its sales. At present, government-ordered, subsidized domestic sales prices are set at 55 percent below European market levels. Gazprom estimates that these domestic-market subsidies have prompted losses of $\$ 49$ billion over the last 10 years. Such losses have hurt Russia's ability to make investments in future production 


\section{The Geopolitics of Gas and Oil Cartels and the Changing Middle East}

capacity. To allow Gazprom to win a gas price war for European market share, Gazprom had been pushing the Russian government to gradually increase domestic gas prices to reach parity with those in Europe. Lifting the price subsidy and reforming the state-controlled gas transportation network would also allow private Russian entities to increase their natural gas production and exports. If these reforms were to be adopted, Russia would have a greater chance of success in a price war with Qatar. Earlier in 2011, Moscow announced plans to increase domestic gas prices by 15 percent.

Despite the potential risks to domestic stability, the geopolitical benefits to Russia from waging a price war under the current situation could become significant if Russia feels it must protect its long-term interests as an energy supplier. Russia could benefit both economically and geopolitically in the long run if it succeeds in coercing either Saudi Arabia or Qatar, or both, into a coalition by creating intense competition for market share. However, in considering a gas price war with Qatar, Russia has to take into account the impact of low natural gas prices on its earnings from oil sales. For Qatar, low gas prices could be beneficial in the long run by enticing more energy buyers. For example, China and Japan, which currently burn oil for electricity generation and industrial activity, could switch to natural gas. In that case, lower prices for gas might be made up from higher export sales for Qatar over the long run. Moreover, rising demand for natural gas at the expense of oil would eventually bring a recovery in gas prices in the longer term as Qatar solidifies a larger market share.

In contrast, for Russia, losing oil market share in order to protect its position in natural gas will be more costly in economic terms. Russia's receipts from international oil sales amounted to $\$ 148.7$ billion in 2009 , or about 40 percent of Russia's federal budget. Revenues from natural gas were far lower at $\$ 42$ billion. For every dollar Moscow earns selling a barrel of oil to Europe,

it earns only 86 cents on the equivalent volume of natural gas exported there. Thus, to the extent that low gas prices reduce demand for oil and eventually lower the prices for both oil and gas, Russia would face a higher price for any geopolitical gains that might come from higher gas sales. Thus, Russia has to consider a more complex set of trade-offs. 


\section{The Geopolitics of Gas and Oil Cartels and the Changing Middle East}

Either Russia or Saudi Arabia can wage a price war in the oil market. As mentioned earlier, Saudi Arabia did this successfully in the mid-1980s and again in 1998 to knock out competitors and achieve geopolitical goals. During the 1986 oil price war, the Soviet Union's response to the Saudi challenge was constrained by its limited financial resources and by a badly managed oil sector. Saudi Arabia at the time had more than 7 million barrels per day (b/d) of spare production capacity available to dump on oil markets virtually instantaneously, while the USSR would have had difficulties changing its oil production profile even over several years. Today, however, the situation is more equal. Saudi Arabia has less spare capacity immediately available (only about 1 to 2 million $\mathrm{b} / \mathrm{d}$ ) and it will be quite expensive for Saudi Arabia to bring on new oil fields. The Kingdom has spent $\$ 14$ billion since 2005 trying to increase its oil production capacity from 10 million b/d to 12.5 million b/d. This has proved difficult and Saudi Arabia, whose capacity is now estimated at 11.5 million $\mathrm{b} / \mathrm{d}$, is still working on the giant Manifa field to meet its 12.5 million b/d immediate-term capacity target. Future investment in a new tranche of production capacity is likely to be even more expensive, given that the Kingdom will have to shift to areas that have more complex geology and require greater technological intervention.

Moreover, in light of new regional and internal challenges, Saudi Arabia is facing competing priorities with higher spending requirements on social services and defense. In an effort to respond to increased instability across the Middle East, King Abdullah ordered sweeping spending increases of $\$ 67$ billion in March 2011 for housing, job creation, and the military, on top of a $\$ 36$ billion handout to citizens in February. The pressure for higher defense and social spending will make it harder for the government to justify a massive campaign to expand its oil sector. It will not be as easy for Saudi Arabia to mobilize a major price war at this time. ${ }^{26}$

However, it would be premature to draw the conclusion that Saudi Arabia will no longer be willing to wage a price war. Its interest in carrying the spare capacity to wage a credible price war goes beyond its security relationship with the United States. Saudi Arabia gains international clout from its ability to guard the global economy by raising oil output and lowering oil prices. Moreover, Riyadh's ability to threaten other oil producers that it could flood the oil market is a critical aspect buttressing its leadership role inside OPEC and gives the country regional clout as well. Indeed, among the best levers Saudi Arabia has to influence regional politics is its ability to 


\section{The Geopolitics of Gas and Oil Cartels and the Changing Middle East}

dramatically lower the price of oil. Saudi Arabia has flooded the oil market for geopolitical reasons in the past, and could arguably do so again. For example, Saudi Arabia has made it clear that it aims to draw the line against Iranian expansionism. ${ }^{27}$ Iran is dependent on oil revenues for more than 65 percent of its government revenue. In contrast, the Kingdom is in a position to withstand a period of low oil prices. Thus, Saudi Arabia's ability to wage a price war is a major tool it can use to diminish Iranian power in the region and weaken Iran's position as a regional military and political rival to the Kingdom. The ability to wage an oil price war also helps the Kingdom to guard against other producers with large oil reserves, such as Iraq, from taking over its oil market share. In fact, Iraq has expressed the ambition to reach 10 to 12 million $\mathrm{b} / \mathrm{d}$ of production by 2017. This level is commensurate with Saudi Arabia's capacity. Rising Iraqi output could alter the balance of political power within OPEC and challenge Saudi Arabia's current leadership. Iraqi oil reserves are considered very low-cost to develop and are competitive with those of Saudi Arabia. In summary, while the costs of maintaining enough spare capacity to wage a price war have risen for Saudi Arabia, there are still many geopolitical incentives for the Kingdom to maintain this capability. This includes contributing to its security by weakening Iran and by remaining important to the United States, which would then be more apt to provide security guarantees in exchange for the free flow of oil. ${ }^{28}$

We now turn our attention to Russia. Its incentives regarding an oil price war have also changed since the 1980s. In the 1980s, the USSR state-controlled sector would have had difficulty responding to a price war with higher investment and rising output. The USSR had severe financial problems and its aged oil sector was failing badly. In contrast, Russia now has a relatively reformed and modernized oil sector that could tap private investment if Moscow provides attractive tax incentives. In 2010, Russia made adjustments to its tax regime to ensure its oil production stayed above 10 million b/d. Analysts believe that a more positive tax environment, including exemptions from export duties, will allow Russia to mobilize new investments quickly, allowing it to raise its production capacity by several million barrels a day. One problem with this strategy is that the Russian government relies heavily on oil royalties and export taxes to cover its federal budget. Lowering such taxes would be problematic for Moscow if oil revenues were also falling due to declining international oil prices resulting from a price war. It is worth mentioning, however, that Moscow has tended to favor geopolitical benefits over 


\section{The Geopolitics of Gas and Oil Cartels and the Changing Middle East}

economic costs. Recent deals between state-run oil conglomerate Rosneft and international major oil companies, a reversal of past policies designed to renationalize and push the very same companies out of Russia, indicate that Russia has an interest in expanding its output, even at the cost of sharing profits with Western firms. ${ }^{29}$

Finally, we cannot rule out the possibility of Russia waging an oil and gas price war against both Saudi Arabia and Qatar. If both oil prices and natural gas prices go down at the same time, Russia does not have to worry as much about losing its oil share for its lower-valued productnatural gas. Though Russia's overall earnings will slide, a price war in both commodities would imply that structural changes that lead to natural gas permanently taking market share from oil would be less likely to take place. At the same time, more voluminous, cheap oil and gas exports from Russia might help Moscow reinstate itself geopolitically in Europe, and to a lesser extent in the United States, as its cheap energy might prove irresistible despite Russia's threat of the "energy weapon" in recent international discourse. The EU might try to impose a principled cap on how much energy it will buy from Russia, but the argument will definitely be made that Moscow can be counted on to establish friendlier relations, since so much Russian capital would be on the line, given the new production potential. Such a strategy might be even more convincing if Russia were to achieve higher oil and gas production by allowing foreign direct investment by European and American oil companies, as its recent overtures - first to BP and then to Chevron and ExxonMobil—seem to imply. Utilizing this strategy, Russia might inject itself between Saudi Arabia and the United States at a time when U.S.-Saudi tension is rising over democratization in the Middle East. Russia would also have the benefit of establishing higher market share, which would eventually re-establish, and even expand, its geopolitical importance as a major energy supplier to the West. This strategy could be a geopolitical win-win for Russia if it leads to extra market share, renders the United States and Europe more dependent on its energy supplies, and forces Saudi Arabia to consider a larger energy coalition with Moscow at the helm. 


\section{The Geopolitics of Gas and Oil Cartels and the Changing Middle East}

\section{An Extension: The Implications of the Democratization of the Middle East}

Our model's prediction that the status quo alignment of interests in the energy markets is stable depends critically on the assumption that Saudi Arabia and Qatar view their alliances with the United States as central to their geopolitical interests. More specifically, in our model this assumption prevents the formation of a coalition between Russia and Saudi Arabia in the oil market, and between Russia and Qatar in the natural gas market. However, the "Arab awakening," which continues to unfold, may bring significant changes to the domestic conditions in many of the countries in the region, including Saudi Arabia and Qatar. Such changes would, in turn, create new dynamics in regional relationships and could redefine the countries' economic and security needs. These changes in domestic and regional conditions are likely to result in a decline in U.S. influence in the region, which would in turn reduce the geopolitical payoffs that Saudi Arabia and Qatar derive from their alliances with the United States. If this occurs, our model can no longer rule out the possibility of new stable coalitions involving Russia. We analyze the likelihood of such a scenario next.

The implications of democratization in the Middle East for U.S. influence in the region have already generated much discussion in the media. ${ }^{30}$ Such an argument can also find support in a prominent empirical finding in the body of international relations research, which is that democracies tend not to engage in conflict with each other. ${ }^{31}$ However, others have pointed out - in reference to Egypt, in particular - that there is no guarantee that a popularly elected government will be friendlier to the United States than its autocratic predecessor. ${ }^{32}$ Both sides of these arguments, however, miss a fundamental institutional difference between democracies and non-democracies: the support of a greater proportion of the population and a larger number of internal political coalitions is necessary for a government to stay in power in a democracy. We believe that this difference could lead to a decrease in U.S. influence in the region, including in issues related to energy policy.

The thrust of our argument is as follows. A government's survival in a democracy depends on the support of a larger set of the population than is necessary for authoritarian regimes or monarchies. As some countries move quickly to democracy and others do not, even traditional 


\section{The Geopolitics of Gas and Oil Cartels and the Changing Middle East}

monarchies will be forced to broaden political participation within their borders and widen the distribution of economic benefits and patronage. For instance, since February 2011, both Saudi Arabia and Qatar have revived suspended local elections. The Kingdom reintroduced municipal elections in 2011 in response to a number of small protests held around the Kingdom inspired by protest movements in Tunisia and Egypt. As Saudi and Qatari leaders take popular sentiments into account, it will become more difficult for governments to disregard the reactions of domestic audiences on important economic and security issues in order to satisfy the policy demands of the United States. Consequently, a close relationship with the United States may no longer be sustainable, or it might come at the cost of losing significant domestic support. ${ }^{33}$ Either way, the payoff from cooperating with the United States may decrease, making alternative policy choices more attractive. This may include cooperating with Russia to sell oil and gas at higher prices in order to meet domestic economic and political demands. ${ }^{34}$ In what follows, we develop this argument more rigorously, drawing on the theory of political survival proposed by Bueno de Mesquita et al. $(1999,2003){ }^{35}$

Bueno de Mesquita et al. classify domestic political institutions by defining two key concepts: the winning coalition and the "selectorate." 36 The winning coalition is the subset of the population whose support is necessary for a leader to stay in power. The selectorate is the subset of the population from which the winning coalition is drawn. Democracies have the largest selectorates because they impose the fewest restrictions on who can participate in selecting leaders - usually only an age limit — often applying the majority rule to elections; they also have the largest winning coalitions. Leaders retain their power if their winning coalitions are satisfied with the benefits that the leaders provide for them. Bueno de Mesquita et al. assume that the benefits come in two forms: public goods and private goods. Public goods are enjoyed by all members of a society, while private goods can only be consumed by a member of a leader's winning coalition. Given limited resources at a leader's disposal, the leader must decide how to allocate the resources between these two types of goods to maximize his chance of staying in office. If the winning coalition is small, then it is optimal to provide private goods to keep the members of the winning coalition happy. However, if the winning coalition is large, as in a democracy, it is less efficient to divide limited resources among a large number of people, because the increase in the individual benefit can be negligible. Thus, the theory predicts that 


\section{The Geopolitics of Gas and Oil Cartels and the Changing Middle East}

democratic leaders will be more inclined to provide public goods whose benefit does not diminish with an increase in the number of people enjoying them.

Applying the theory of the selectorate and winning coalition, we argue that leaders can conduct foreign policies with a primary goal of buying support with private goods for their supporters, or with a goal of providing public goods for the population at large. Traditionally, the United States has exerted influence on the foreign policies of the regimes in the Middle East by negotiating with a small set of political elites. Such an approach has worked well because the regimes were autocratic or monarchic, and the political survival of the leaders only depended on making a small subset of the population (i.e., the winning coalition) happy with the private goods that they derived from the policies. Democratization, on the other hand, means that foreign policies aim to satisfy a significantly expanded winning coalition, which makes providing public goods with foreign policies more attractive for a government. Providing more public goods requires higher oil revenues, which implies high oil prices; therefore, a democratically elected government will be much more constrained in keeping the prices low in exchange for security benefits from the United States, especially if the security benefits can also come from alternative sources.

Such a shift in the main factor behind foreign policy decision-making will occur if Saudi Arabia and, to a lesser degree, Qatar become more democratic. ${ }^{37}$ Even if these countries remain nondemocratic, an increased sensitivity of the ruling class in the two countries to the preference of a larger segment of the society will have a similar (if smaller) effect. Saudi Arabia has already instituted a number of domestic reforms in response to the current political atmosphere in the Middle East. The Kingdom implemented a new round of municipal elections at the end of September 2011, with more than 5,000 male candidates on the ballot. According to the electoral commission, more than 1.2 million Saudi men registered to vote. The first phase of the elections was held in April 2011. Voters selected representatives to fill half the seats in the Kingdom's 285 municipal councils, with the other half appointed by the government. Women were not allowed to participate in recent voting, although the king has decreed that women will be allowed to participate in the next elections, theoretically to be held in four years. 


\section{The Geopolitics of Gas and Oil Cartels and the Changing Middle East}

Besides prompting the Saudi government to reinstitute municipal elections, the tide of democratization across the region has made the Saudi government realize that handing out private economic goods just to the elite is no longer a sustainable practice in the Middle East. ${ }^{38}$ At the end of February 2011, King Abdullah announced a $\$ 36$ billion package of state support measures, including the creation of a one-year unemployment benefit payment to jobless Saudis, admission of all Saudis studying abroad into a state scholarship system, codification of a 15 percent increase in government salaries, and increased availability of home loans. The government also reiterated that it would not eliminate an inflation allowance that had boosted salaries of state employees by 15 percent over the previous three years; the allowance became part of each employee's permanent salary. A second Saudi tranche announced in March 2011 called for an additional $\$ 93$ billion to be dedicated to social benefits. In a set of royal decrees, the Saudi government boosted welfare benefits, established a minimum wage of $\$ 800$ a month for state employees, gave bonuses to public sector workers and students, and committed resources for new housing. Some $\$ 67$ billion alone was set aside for building 500,000 housing units and $\$ 4.3$ billion was targeted for constructing more medical facilities. In addition, King Abdullah called for the creation of 60,000 security jobs within the Interior Ministry and pledged more financial resources for the religious police.

The combined $\$ 130$ billion of extra spending amounts to nearly 30 percent of Saudi Arabia's annual economic output. Such generous gestures will no doubt put strains on the Saudi government budget. Moreover, the living standards for average Saudis have declined in the past two decades, with poverty hitting over 13 percent of the population in 2010, from virtually none

in the $1980 \mathrm{~s} .{ }^{39}$ Some analysts predict the Kingdom will have trouble maintaining higher spending on social services and military salaries in the coming years, with rising national budgets requiring crude oil prices of $\$ 88$ a barrel in 2011 to balance expenditures with income, increasing to $\$ 110$ a barrel to prevent budget deficits by 2015 . $^{40}$

In the short run, the ability of the Saudi monarchy to hold onto the reins of power seems stable, as economic handouts, targeted repression, and the promise of reform have so far kept the vast majority of Saudis off the streets. In the long run, however, as expectations of the population increasingly need to be met with broadly distributed benefits, higher oil prices will become a 


\section{The Geopolitics of Gas and Oil Cartels and the Changing Middle East}

more important imperative for Saudi Arabia as it seeks popular support, making a Saudi-Russia coalition much more attractive than it has been in the past.

Moreover, the democratization of neighboring countries around Saudi Arabia and Qatar will likely change the regional dynamics, creating new security needs that may not be met by the countries' strong relationships with the United States. As mentioned earlier, we believe that Saudi Arabia cares about being the spiritual leader of the Arab world as well as holding on to its market power in the oil market. The desire to be the religious leader is not merely of symbolic importance to Saudi Arabia; it translates to a political power that can hold sway over other monarchies and the Arab population at large. This power, thus, has security implications for Saudi Arabia's internal and external affairs. Such a status may be challenged if a nearby Arab state becomes democratic, because a democratically elected government may be less likely to make foreign policy concessions that are in the interest of Saudi Arabia and might also undermine its religious leadership. Moreover, any additional democratically elected Shiite governments beyond Iraq will rattle Saudi Arabia even further out of concern that the government would be under the influence of Iran. In such a scenario, even if Saudi Arabia has the ability to coerce the government to change policy by military means, such an action is likely to draw criticism from the United States, as indicated by the reactions of the United States to Saudi Arabia's recent intervention in Bahrain. While a special security pact with the United States is critical for Saudi Arabia to counter external military threats, particularly those from Iran, U.S. support for democracy building is becoming increasingly inconvenient, and potentially even threatening, to the Saudi monarchy as its citizens watch U.S. support for regime change in more and more regional countries. ${ }^{41}$ There is no similar democratization concern with respect to Russia.

An important question is whether Russia, if properly motivated, could be more effective than the United States in helping Saudi Arabia reduce the Iranian threat. Iran has its own ambition of becoming the religious leader of the Shiite world, and it desires to challenge Saudi Arabia's dominance in the international oil market. Moreover, the nuclear weapon that Tehran is suspected of developing poses a grave threat to Saudi Arabia's national security. While the United States has actively engaged the international community to inhibit Iran's ability to attain 


\section{The Geopolitics of Gas and Oil Cartels and the Changing Middle East}

nuclear weapons by organizing economic sanctions against Tehran, Russia has tacitly encouraged Iran's policy by providing critical technical assistance to Iran's nuclear program. In fact, Russia has found that its geopolitical power can be enhanced by maintaining a friendly relationship with Iran while the latter is faced with isolation in the international community. First, Russia's military cooperation with Iran poses a threat to its major competing Middle East energy suppliers, namely Saudi Arabia and Qatar. By backing Iran militarily, Russia gains access to a regional proxy that can directly influence the security of Saudi Arabia and Qatar. This reality acts as a constraint on Saudi Arabia and Qatar by potentially raising the geopolitical and security costs to pursue energy policies hostile to Russian interests. Second, by providing technical assistance to keep Iran's nuclear program alive (but not to the extent that Iran attains the ability to produce nuclear weapons in the near future), Russia essentially ensures that international economic sanctions on Iran continue so that Iran does not have opportunities to compete with Russia in the gas market, specifically in Europe. In other words, Iran's nuclear program remains in part a function of Russian assistance, which serves Russia's interest in the energy market.

In addition, the tensions between the United States and Iran over its nuclear program are of concern to international oil markets, buttressing oil prices and thereby enhancing Russian oil revenues. Consequently, Saudi Arabia has a clear incentive to woo Russia away from Iran. To achieve this kind of new realignment, Saudi Arabia has offered concessions on arms sales and cooperation in the oil market. According to a report in the Russian daily Kommersant, Saud AlFaisal, Saudi Arabia's foreign minister, made it clear during a trip he made to Moscow in February 2008 that the Kingdom would offer Russia lucrative arms contracts only in exchange

for Moscow curtailing military cooperation with Iran. ${ }^{42}$ Under changing political trends resulting from the Arab Spring, it is conceivable that Saudi Arabia may seek Russia's cooperation on the Iranian nuclear program by giving in to Russia's push for shared power in the oil market. According to some estimates, new trends of oversupply in the international gas market and delays in Iranian gas export infrastructure development mean that Iran will not be a serious competitor to Russia in the gas market for at least 15 to 20 years. ${ }^{43}$ That means that Russia's goal of blocking Iranian gas development has largely been achieved, leaving only other motivations in place. One such alternative motivation underpinning Russia's military and nuclear assistance to Tehran is Iran's ability to threaten Saudi Arabia and Qatar militarily and thereby force them to 


\section{The Geopolitics of Gas and Oil Cartels and the Changing Middle East}

adjust their oil and gas policies. At OPEC gatherings in the late 2000s, Russian Prime Minister Igor Sechin pressed Saudi representatives for higher oil prices by describing how such a RussianIranian military alliance was adverse to Saudi interests. Consequently, it would not be surprising if Russia would be more amenable to a deal with Saudi Arabia for a new coalition on oil prices in exchange for its cooperation in constraining Iran. Such a possibility may imply a significant increase in geopolitical payoffs for Saudi Arabia if it considers an alternative coalition with Russia at a time when the geopolitical payoffs for Saudi Arabia from the traditional oil-forsecurity arrangement with the United States may be declining. While a stronger coalition between Saudi Arabia and Russia may not be imminent, a scenario under which such a coalition may become more compelling in the future appears to be possible. ${ }^{44}$

In contrast to Saudi Arabia, the regional dynamics are not likely to change Qatar's relationship with the United States significantly. Qatar is a small and wealthy country with limited foreign policy goals, the most important of which is to protect its security and interests against bigger regional powers, namely Iran and Saudi Arabia. Qatar now enjoys the highest per capita income in the world and with financial success has come international prestige, as indicated by hosting important events such as the World Cup. Therefore, its population is likely to be less concerned about higher gas revenues, especially given the difficulty of achieving that in a well-supplied global market. Thus, security issues loom large and, in this sense, a strong military alliance with the United States is not easily substitutable, except by a similar alliance with Russia. Given that there is a direct conflict of economic interests between Qatar and Russia over natural gas, it is difficult to envision that Qatar will switch its allegiance to Russia. We conclude that we are far more likely to observe a Russo-Saudi coalition in the oil market rather than a gas cartel.

\section{Conclusion}

In this study we analyzed the likelihood of a new configuration of coalitions that might emerge in energy markets. We focused our attention on the three most important resource exporters in the world: Russia, Saudi Arabia, and Qatar. Currently, Saudi Arabia is the leader of OPEC and, as such, it enjoys monopoly power on setting the oil price. On the other hand, due to its vast reserves and low production costs, Qatar, as the world's largest exporter of LNG, has a similar 


\section{The Geopolitics of Gas and Oil Cartels and the Changing Middle East}

level of influence in the natural gas market. Russia is endowed with rich reserves of both resources, but has not been able to play the role of an equal partner in either market due to domestic economic and political constraints. As a result, Russia faces the risk that Saudi Arabia and Qatar, with backing from the United States, can initiate a "two-front war" in global energy markets. Russia has attempted to remove this threat by creating a gas cartel with Qatar, and also by initiating a discussion of joining OPEC. Neither effort has paid off so far.

The starting point of our analysis was to evaluate if these are temporary setbacks for Russia or if there is a deeper geopolitical logic to the outcomes. Our model suggests that, indeed, the geopolitical calculations of Saudi Arabia and Qatar have rendered the status quo stable. While existing research takes only economic interests into account, we based our analysis on careful consideration of the economic and political payoffs resulting from energy policies. Taking both factors into consideration, we argued that it is in the interest of both Saudi Arabia and Qatar to maintain close ties with the United States. This, however, undermines their economic interest in forming a coalition with Russia. We argued that the geopolitical payoffs have dominated the economic payoffs for both countries thus far.

We provide an analysis of the likelihood of price wars in energy markets. Our analysis identified two conditions under which price wars can occur. First, there can be a price war in the market for natural gas if Russia is determined to protect, or even increase, its market share in Europe by knocking out other higher cost producers. We find that competitive pressures created by shale gas could make this option more appealing to Russia. Second, even if it is very costly, Saudi Arabia can use an oil price war as a foreign policy tool to weaken Iran's position as a regional military and political rival to the Kingdom. Saudi Arabia may also use the strategy to guard against other producers with large oil reserves, such as Iraq, from taking over its oil market share and replacing it as the most important global supplier to the industrialized world.

Finally, we considered an important recent development in the Middle East that may change the geopolitical payoffs for Saudi Arabia and Qatar-the democratization movement. According to our model, significant changes in geopolitical payoffs may bring about new coalitions involving Russia. Applying the theory of political survival, we argued that any changes in domestic 


\section{The Geopolitics of Gas and Oil Cartels and the Changing Middle East}

conditions - even if they are well short of a regime change_-give the rulers of Saudi Arabia and Qatar an incentive to become more sensitive to domestic reactions to their foreign policies. This trend, we argue, is likely to reduce the payoffs resulting from maintaining special relationships with the United States. Moreover, new security needs due to changing regional dynamics could push Saudi Arabia toward a warmer relationship with Russia. Thus, we cannot rule out the possibility that Saudi Arabia may form a stronger coalition with Russia in the oil market in the future, possibly by allowing Russia to join OPEC. We do not envision a similarly significant change in Qatar's geopolitical payoffs from its relationship with the United States. Thus, a gas cartel seems unlikely in the perceivable future. 


\section{The Geopolitics of Gas and Oil Cartels and the Changing Middle East}

\section{Endnotes}

1. See Jareer Elass and Amy Myers Jaffe, "The History and Politics of Russia's Relations with OPEC," (working paper, James A. Baker III Institute for Public Policy, Rice University, Houston, TX, May 2009).

2. See "resource wars" literature by Michael Klare and Nader Elhefnawy. The concept, first introduced by Michael Klare, theorizes that diminishing supplies of vital materials will raise the risk of conflict across the globe and "introduce new stresses into the international system." Michael Klare, Resource Wars (New York: Henry Holt and Company, 2001). Klare also notes: "No highly industrialized society can survive at present without substantial supplies of oil, and so any significant threat to the continued availability of this resource will prove a cause of crisis, and, in extreme cases, provoke the use of military force." Elhefnawy takes the argument a step further, asserting that since the U.S. economy is the most oil dependent among world powers, “the United States could ultimately lose its position as a world power ... just as the U.K.'s position declined along with the age of coal and steam that it (the U.K.) pioneered." See Nader Elhefnawy, “The Impending Oil Shock,” Survival 50, no. 2 (June 2008).

3. For a detailed description of Russia's energy diplomacy since the breakup of the Soviet Union, see Edward L. Morse and James Richard, “The Battle for Energy Dominance,” Foreign Affairs, March/April 2002. Also, Amy Myers Jaffe and Robert Manning, "Russia, Energy and the West," Survival 43, no. 2 (Summer 2001); and Amy Myers Jaffe and Ronald Soligo, "Energy Security: The Russian Connection," in Energy Security and Global Politics: The Militarization of Resource Management, eds. Daniel Moran and James A. Russell (Abington: Routledge, 2008). Russian Energy Minister Sergei Shmatko has said that Russia had "such a significant position in the high society of world oil, a Russian factor should appear."

4. Stanley Reed, "Russia Weighs In At OPEC Meeting,” Business Week, September 9, 2008. Also, see Jareer Elass and Amy Myers Jaffe, "The History and Politics of Russians Relations with OPEC" (working paper, James A. Baker III Institute for Public Policy, Rice University, Houston, TX).

5. Andrei Glazov, "Gazprom Extends Global Reach,” Nefte Compass, November 20, 2008; “Gazprom Still Pushing Troika, China Sales,” World Gas Intelligence, November 19, 2008. 6. "Putin says 'cheap gas era' ending," BBC News, December 23, 2008. 


\section{The Geopolitics of Gas and Oil Cartels and the Changing Middle East}

7. See Daniel Canty, "Analysis: Could collective gas pricing be upon us?" Arabian OilandGas.com, May 20t, 2010; and Adal Mirza, "Time for a Gas OPEC?" MEED no. 17 (April 2010).

8. Dominique Finon, "Russia and the 'Gas-OPEC': Real or Perceived Threat?" IFRI Russia/NIS Center (November 2007).

9. Obindah N. Wagbara, "How Would the Gas Exporting Countries Forum Influence Gas Trade?” Energy Policy 35 (2007). Also see Kenneth B. Medlock III, Amy Jaffe, and Peter R. Hartley, "Shale Gas and U.S. National Security" (working paper, James A. Baker III Institute for Public Policy, Rice University, Houston, TX, July 2011).

10. We do not consider Iran as a player in our model because even though it is the third largest reserve holder of natural gas, longstanding international economic sanctions against the country have prevented Iran from developing export capacity. At this juncture, given market competition and political risk, it could take Iran as long as 15 to 20 years before it could become a major player in the global gas scene. See Kenneth B. Medlock III, Amy Myers Jaffe, and Peter R. Hartley, "Shale Gas and U.S. National Security" (working paper, James A. Baker III Institute for Public Policy, Rice University, Houston, TX, July 2011).

11. Kissinger noted: "[G]ame theory's major contribution was the payoff matrix, in that it made people realize that their adversaries were looking at the conflict in a similar way as they were." In "On the State of Art in Game Theory: An Interview with Robert Aumann, Eric Van Damme, Interviewer," Games and Economic Behavior 24 (1998): 181-210.

12. Regan Doherty, “Tiny Qatar Wielding Powerful Political Punch,” Reuters, January $18,2012$.

13. Russia also cares deeply about securing its borders and preventing separatism in its far-flung regions as well as about other international matters, but for the purposes of this study, we consider those objectives most relevant to the questions at hand.

14. For a discussion on Russia's fears over territorial matters and permeable borders overshadowing its interest in optimizing oil and gas sales to China, see Nodari Simonia, "Russian Energy Policy in East Siberia and the Far East" (paper prepared for the study "The Energy Dimension in Russian Global Strategy, James A. Baker III Institute for Public Policy, Rice University, Houston, TX, October 25, 2004), http://bakerinstitute.org/publications/russianenergy-policy-in-east- siberia-and-the-far-east. 


\section{The Geopolitics of Gas and Oil Cartels and the Changing Middle East}

15. One advantage of the cooperative approach is that it allows us to characterize stable outcomes without having to specify details of the underlying interactions that are not central to our analysis and can seem arbitrary, such as the order of play.

16. We assume that producers who are not members of the blocking coalition will do the best for themselves, given that $\mathrm{C}$ is formed.

17. This weakening of military and regional influence could be ameliorated if Saudi Arabia could make the coalition conditional on Russia's cooperation on containing Iran's access to military arms.

18. Regan Doherty, “Tiny Qatar Wielding Powerful Political Punch,” Reuters, January $18,2012$.

19. Kohei Hashimoto, Jareer Elass, and Stacy L. Eller, "Liquefied Natural Gas from Qatar: The Qatar Gas Project," in Natural Gas and Geopolitics from 1970 to 2030 (Cambridge: Cambridge University Press, 2006).

20. Ibid.

21. Christopher M. Blanchard, "Qatar: Background and U.S. Relations," U.S. Congressional Research Service (May 16, 2011).

22. Ibid.

23. Ibid.

24. Kenneth B. Medlock III, Amy Myers Jaffe, and Peter R. Hartley, "Shale Gas and U.S. National Security" (working paper, James A. Baker III Institute for Public Policy, Rice University, Houston, TX, July 2011).

25. Mahmoud El-Gamal and Amy Myers Jaffe, Oil, Dollars, Debt, and Crises: The Global Curse of Black Gold (Cambridge: Cambridge University Press, 2010).

26. In fact, some analysts have called into question whether Saudi Arabia will continue to make the massive investments it will take for the Kingdom to carry enough spare productive capacity to make credible a threat of an oil price war. As Robert McNally and Michael Levi point out in their Foreign Affairs piece, "A Crude Predicament": "With U.S.-Saudi ties having frayed over the last decade, Riyadh's motivation to continue contributing to its security partnership with the United States by maintaining spare crude capacity has diminished ... today, Riyadh is less certain about the strength of its alliance with Washington and may thus be less willing to incur the costs and risks involved in contributing to the U.S.-Saudi partnerships in 


\section{The Geopolitics of Gas and Oil Cartels and the Changing Middle East}

these ways (flooding the oil market)." See Robert McNally and Michael Levi, "A Crude Predicament: The Era of Volatile Oil Prices," Foreign Affairs, July/August 2011, 100.

27. Michael Slackman and Ethan Bronner, "Saudis, Fearful of Iran, Send Troops to Bahrain to Quell Protests," New York Times, March 15, 2011.

28. If Riyadh remains a monarchy and its neighbors become democracies, its role will remain important, as increased production might be less likely for its democratic neighbors than for a monarchy.

29. Wall Street Journal, “Exxon Wins Arctic Deal, Gives Russia U.S. Access,” August 31, 2011, http://online.wsj.com/article/SB10001424053111904199404576540350519892620.html.

30. For examples, see Daniel Byman, "Beware the Perils of a Libya After Gaddafi Has Gone," Financial Times, June 20, 2011; Tony Karon, "Will Egypt's Military Hijack Its Revolution?" Time, July 19, 2011; and James Zogby, "Diminishing Goodwill for U.S. Middle East Policy," Foreign Policy, July 15, 2011.

31. Bruce Russett, "Democracy and Peace," in Choices in World Politics, ed. Russett et al., (New York: W.H. Freeman, 1989).

32. In a recent poll conducted by the Pew Global Attitudes Project, only 20 percent of Egyptians surveyed indicated a favorable view of the United States. Egypt is already pursuing a foreign policy more independent of the United States. For example, Egypt brokered a Palestinian unity agreement in May without consulting Washington. "Egyptians Embrace Revolt Leaders, Religious Parties and Military As Well," Pew Research Center, (April 25, 2011).

33. Some regional commentators are already predicting this outcome. Writes former U.S. foreign policy advisor Aaron David Miller: "The gaps separating American values, interests, and policies could actually grow, and the space available to the United States to pursue its policiesfrom Iran to Gaza to the Arab-Israeli peace process - could contract. The growing influence of Arab popular opinion on the actions of Arab governments and the absence of strong leaders will make it much tougher for the United States to pursue its traditional policies. For America, the Arab Spring may well prove to be more an Arab Winter." Aaron David Miller, "For America, an Arab Winter," Wilson Quarterly (Summer 2011). Elham Fakhro and Emile Hokayem, in "Waking the Arabs," Survival 52, no. 2 (April-May 2011), make a similar point about the Arab Spring itself: "Another consequence of the recent unrest is that governments, seeking to reflect more closely the views of their populations, will become less pliable regarding Western foreign- 


\section{The Geopolitics of Gas and Oil Cartels and the Changing Middle East}

policy preferences. As Western and Middle Eastern values converge, their societies' concept of interests may in fact grow farther apart."

34. Khair El Din Haseeb notes, "Transformation of these regimes into democratic ones which incorporate the participation of their peoples in primary decision-making processes will preclude their national security from remaining at the mercy of the United States ... The Arab peoples will demand just prices for their vital oil and gas resources, commensurate with the price increases of various goods in the West. They will not permit their regimes to continue to sell oil at current prices." "On the Arab Democratic Spring: Lessons Derived," Contemporary Arab Affairs, April 21, 2011.

35. Bruce Bueno de Mesquita, Alastair Smith, Randolph M. Siverson, and James D. Morrow, "An Institutional Explanation of the Democratic Peace," American Political Science Review 93, no. 4 (1999): 791-808; Bruce Bueno de Mesquita, Alastair Smith, Randolph M. Siverson, and James D. Morrow, The Logic of Political Survival (Cambridge: The MIT Press, 2003).

36. Ibid.

37. In Qatar, the population is so small, and private benefits are so easy to distribute, that we expect much less change in foreign policy even if the country is democratized. Qataris will still have security as their number one concern, and it is likely that U.S. protection will continue to be seen as central toward that goal.

38. The narrow elite who enjoyed private goods from the government of Tunisia are said to be an instrumental factor leading to the recent demise of former Tunisian President Zine El Abidine Ben Ali.

39. The poverty level in Saudi Arabia is set at an income of $\$ 1,015$ per month., Nawaf Obaid, “There Will Be No Uprising in Saudi Arabia,” Foreign Policy, March 10, 2011.

40. The Institute of International Finance, an international banking trade group, predicted in its March 2011 report that, while the Saudi government needs to average $\$ 88$ a barrel for its crude to balance the budget this year - up from $\$ 68$ a barrel in 2010 - Riyadh will begin facing budget deficits unless it can sell its oil for an average of $\$ 110$ a barrel by 2015 .

41. White House spokesman Jay Carney told reporters that we [the U.S.] believe that political dialogue is the way to address the unrest that has occurred in the region in Bahrain and 


\section{The Geopolitics of Gas and Oil Cartels and the Changing Middle East}

in other countries, and not to, in any way, suppress it. David Sanger and Eric Schmitt, "U.S.Saudi Tensions Intensify with Mideast Turmoil,” New York Times, March 14, 2011.

42. "Putin meets top Saudi official as Russia eyes arms sale," Agence France-Presse, November 23, 2007.

43. Kenneth B. Medlock III, Amy Myers Jaffe, and Peter R. Hartley, "Shale Gas and U.S. National Security" (working paper, James A. Baker III Institute for Public Policy, Rice University, Houston, TX, July 2011).

44. However, one must also consider that the US-Saudi security relationship is not based solely on the threat from Iran and that Russia itself has historically been viewed as a military threat to the Saudi Kingdom. U.S. assistance is also important for internal Saudi stability and for Saudi Arabia's ability to combat militant groups in Yemen and elsewhere in the region. 